Mirjana KEVO, dipl. iur.

sutkinja Općinskog suda u Mostaru i

doktorandica Pravnoga fakultetu Sveučilišta u Mostaru

mirjana.kevo@pravosudje.ba

Minja BELOVIĆ, dipl. iur.

sutkinja Općinskog suda u Mostaru

minja.belovic@pravosudje.ba
UDK: 341.174(4)EU:347.919

341.1:341.32 (497.6).

Primljen: 29. 9. 2021.

Prihvaćen: 12. 11. 2021.

Izvorni znanstveni rad

\title{
POSTUPAK ZA RJEŠAVANJE SPORNOG PRAVNOG PITANJA S OSVRTOM NA PRETHODNI POSTUPAK PRED EUROPSKIM SUDOM PRAVDE
}

Sažetak: Zakon o izmjenama i dopunama Zakona o parničnom postupku Federacije Bosne i Hercegovine iz 2015. godine donio je brojne novine u parnični postupak. Jedna od njih je i uvođenje instituta rješavanja spornog pravnog pitanja. Člankom 14. Zakona o izmjenama i dopunama Zakona o parničnom postupku Federacije Bosne i Hercegovine iz 2015. godine iza čl. 61. dodano je novo poglavlje III. a i čl. 61a. - 61f. pod naslovom - Postupak za rješavanje spornog pravnog pitanja. Razlozi za uvođenjem ovog pravnog instituta u naš pravni sustav ogledaju se u doprinosu pravnoj sigurnosti $i$ jednakosti pred prvostupanjskim sudovima, te u povećanju djelotvornosti i ekonomičnosti postupka. Ovaj se institut uspoređuje s postupkom prethodnog odlučivanja pred Europskim sudom pravde.

U radu će se analizirati odredbe o Postupku za rješavanje spornog pravnog pitanja, a posebna je pozornost dana analizi prakse Vrhovnog suda Federacije Bosne i Hercegovine vezanoj uz ovaj institut. Istražuje se općenito pravna priroda postupka $z a$ rješavanje spornog pravnog pitanja, razmatraju se uvjeti $i$ osobe ovlaštene za njegovo pokretanje, te odluke Vrhovnog suda Federacije Bosne i Hercegovine o spornom pravnom pitanju. Prethodno će biti razmotren postupak prethodnog odlučivanja pred Europskim sudom pravde. Ukazat će se, također, na rješenja u poredbenom pravu.

Ključne riječi: Europski sud, nacionalni sudovi, Vrhovni sud Federacije Bosne i Hercegovine, postupak za rješavanje spornog pravnog pitanja, sporno pravno pitanje. 


\section{UVODNE NAPOMENE}

Posljednjim izmjenama i dopunama Zakona o parničnom postupku Federacije Bosne i Hercegovine, ${ }^{1}$ izmjenama i dopunama Zakona o parničnom postupku Republike Srpske, ${ }^{2}$ te Zakonom o parničnom postupku Brčko Distrikta, ${ }^{3}$ u parnični postupak uveden je potpuno nov procesni institut - postupak za rješavanje spornog pravnog pitanja - kojim se nastojalo ostvariti više različitih ciljeva. Neki od njih ogledaju se, prije svega, u doprinosu pravnoj sigurnosti i jednakosti pred nižim sudovima, a zatim u povećanju djelotvornosti i ekonomičnosti postupka. Ovaj se institut uspoređuje s postupkom prethodnog odlučivanja pred Europskim sudom pravde. Posebno se naglašava da je svrha ovog instituta spriječiti donošenje različitih presuda u većem broju predmeta koji imaju istu činjeničnu i pravnu osnovu, odnosno kada se radi o istovjetnom tužbenom zahtjevu s identičnom procesnom građom da se različito suđenje svede na najmanju moguću mjeru. ${ }^{4}$ Nadalje, uvođenjem ovog instituta ostvaruju se i ciljevi iz čl. 6. stavak 1. Europske konvencije o ljudskim pravima i osnovnim slobodama ${ }^{5}$ o pravu suđenja u razumnom roku, a u skladu s preporukom Komiteta ministara Vijeća Europe R/95/5 o uvođenju i poboljšanju funkcioniranja žalbenih sustava i postupaka u građanskim i trgovačkim predmetima, Glava IV, član 7, točka d (uloga i djelovanje suda trećeg stupnja). Po ovoj preporuci, države članice trebaju razmotriti uvođenje sustava u kome će trećestupanjski sud moći izravno uzeti u razmatranje određeni predmet kako bi prije donošenja prvostupanjske odluke zauzeo pravni stav o prethodnom pravnom pitanju. ${ }^{6}$ Kritika ovog procesnopravnog instituta bila je prije svega usmjerena na

1 Zakon o izmjenama i dopunama Zakona o parničnom postupku Federacije Bosne i Hercegovine (Službene novine FBiH, br. 98/15. - dalje Izmjene ZPP FBiH).

2 Zakon o izmjenama i dopunama Zakona o parničnom postupku Republike Srpske, Službeni glasnik Republike Srpske, br. 6/13. - dalje Izmjene ZPP RS iz 2013. godine.

3 Zakon o parničnom postupku Brčko Distrikta, „Službeni glasnik Brčko Distrikta BiH“ br. 28/18. - dalje ZPP BD.

4 Vidi Obrazloženje Nacrta Zakona o izmjenama i dopunama Zakona o parničnom postupku Federacije Bosne i Hercegovine, Sarajevo, 2013. Dostupno na: http://www. parlamentfbih.gov.ba/dom_naroda/bos/parlament/propisi/uproceduri_2010_2014.htm, El_materijali/Nacrt\%20Zakona\%20o\%20parnicnom\%20postupku.pdf, str. 39. - 40.

5 Čl. 6. stavak 1. Europske konvencije za zaštitu ljudskih prava i temeljnih sloboda glasi dalje EKLJP: "Prilikom utvrđivanja građanskih prava i obveza ili osnovanosti bilo kakve krivične optužbe protiv njega, svatko ima pravo na pravično suđenje i javnu raspravu u razumnom roku pred nezavisnim i nepristranim, zakonom ustanovljenim sudom."

6 Vidi preporuku Komiteta ministara Vijeća Europe R/95/5, glava IV, član 7, točka D (Reccommendation No. R (95)5 of the Committee of Ministers of the Council of Europe), dostupno na: rm.coe.int/CoERMPublicCommonSearchServices/DisplayDCTMContect?documentld $=0900001680505 \mathrm{f} 3 \mathrm{c}$ 
pitanja ugrožava li odluka trećestupanjskog suda (u konkretnim slučajevima bi to bilo Vrhovnog suda Federacije BiH, Vrhovnog suda Republike Srpske, te Apelacionog suda Brčko Distrikta) neovisnost prvostupanjskih sudova, te radi li se o primjeni precedentalnog prava ili samo o prejudicijalnom tumačenju od Vrhovnog suda prema pravilima zauzimanja načelnih pravnih stavova, prije nego što se prvostupanjski postupak okonča. ${ }^{7} \mathrm{U}$ doktrini ne postoji jasan stav o tome je li odluka Vrhovnog suda o spornom pitanju izvor prava. ${ }^{8}$ Prema jednim autorima, ako bi nižestupanjski sudovi bili vezani uz sudsku interpretaciju Vrhovnog suda, kaže se da bi to bio napad na neovisnost nižestupanjskih sudova. Smatra se da se ovdje radi o dva međusobno suprotstavljena interesa - potrebe za jednakom

$7 \quad$ Vidi Salma, M., Postupak za rješavanje spornog pravnog pitanja, Zbornik radova Pravnog fakulteta u Novom Sadu, br. 1, 2012., (dalje - Salma), str. 290. - 293.

8 Odredbe o postupku za rješavanje spornog pravnog pitanja u Republici Srbiji koje su gotovo u cijelosti podudarne s odredbama kojima je ovaj procesni institut uređen u bosanskohercegovačkoj parničnoj proceduri bile su predmetom odlučivanja pred Ustavnim sudom Republike Srbije povodom postupka za ocjenu njihove ustavnosti. Podnositelji zahtjeva pozivali su se na narušavanje načela neovisnosti suda i načela dvostupanjskog odlučivanja. Isticali su i da su ove odredbe u suprotnosti s Ustavom jer "otvaraju mogućnost" da se sudi na temelju pravnih shvaćanja Vrhovnog suda i da sam naslov u zakonskom tekstu „Postupak za rješavanje spornog pravnog pitanja“ upućuje da je riječ o postupku koji prethodi donošenju sudske odluke. Ustavni sud je u svojoj odluci I U 181/2005 odbio zahtjev za ocjenu ustavnosti odredbi čl. 176.-180. ZPP Srbije 2004 s obrazloženjem da Vrhovni sud Srbije rješavajući sporno pravno pitanje ne odlučuje o predmetu spora, već da se odredbama o rješavanju spornog pravnog pitanja daje mogućnost Vrhovnom sudu Srbije da zauzme stav o pravnom pitanju koje se pojavi kao sporno u postupku pred prvostupanjskim sudom, pod uvjetom da se određeno pravno pitanje pojavilo kao sporno u većem broju predmeta te da je ono od prejudicijelnog značaja za odlučivanje o predmetu pred prvostupanjskim sudovima. Nadalje, po stavu Ustavnog suda iz odredbe čl. 177. st. 1. ZPP-a Srbije 2004, proizlazi da prvostupanjski sud u obraćanju Vrhovnom sudu može da iznese i vlastito tumačenje spornog pravnog pitanja, što dalje znači da se ne radi o uspostavljanju precedenata, već o zauzimanju pravnog shvaćanja o određenom pravnom pitanju koje je od prejudicijelnog značaja za odluku u većem broju predmeta. U pravnom shvaćanju koje zauzima, stav Vrhovnog suda nema karakter odluke o konkretnoj pravnoj stvari na koju se može izjaviti pravni lijek, već se kao depersonalizirano pravno shvaćanje objavljuje u Biltenu Vrhovnog suda. Prema ocjeni Ustavnog suda Srbije, odredbe čl. 176.-180. ZPP-a 2004 Srbije predstavljuju mehanizam kojim se kroz zauzimanje pravnog shvaćanja Vrhovnog suda osigurava pravna sigurnost $\mathrm{i}$ jednakost u postupcima pred nižestupanjskim sudovima, kao i suđenje u razumnom roku. Kako se tim odredbama ne isključuje mogućnost ulaganja pravnih lijekova protiv pojedinačnih odluka prvostupanjskih sudova, njima se ne narušava načelo neovisnosti sudova i načelo dvostupanjskog odlučivanja niti se protivno odredbi čl. 96. Ustava Republike Srbije uvodi suđenje na osnovu pravnih shvaćanja Vrhovnog suda Srbije. Vidi Ustavnog suda Srbije br. I U 1881/2005, „Službeni glasnik RS“, br. 106/06 od 24. 11. 2006. godine. 
primjenom i tumačenjem prava koje osigurava Vrhovni sud kad zauzima stav o spornom pravnom odnosu koji treba primjenjivati u svim istim pravnim situacijama, i ustavne i zakonske neovisnosti nižestupanjskih sudova od višestupanjskih sudova u tumačenju prava. ${ }^{9}$ Drugi autori smatraju da ovaj institut ne mijenja stav da sudska praksa nije, formalno-pravno, izvor građanskog procesnog prava. Uvodeći novi postupak, tzv. postupak za rješavanje spornog pravnog pitanja, zakonodavac je označio autoritet najviše sudske instance čiji stavovi o spornim pravnim pitanjima imaju nesporan utjecaj na odlučivanje sudova nižeg ranga, ali još uvijek nedovoljan da bi se o sudskoj praksi govorilo kao o izvoru prava. ${ }^{10}$ Bez obzira što je odredbom čl. 61 đ. ZPP RS izričito predviđeno "ako je Vrhovni sud riješio sporno pravno pitanje, stranke u postupku u kome se postavlja isto sporno pravno pitanje nemaju pravo tražiti njegovo rješavanje u parnici koja je u tijeku" i što se može indirektno zaključiti da odluka Vrhovnog suda obvezuje nižestupanjske sudove, nikako se ne može zaključiti da interpretacija određenog uslovljavajućeg odnosa predstavlja izvor prava. ${ }^{11}$

Mišljenja smo da odluke Vrhovnog suda $\mathrm{FBiH}$ o spornom pravnom pitanju ne predstavljaju izvor prava. Vrhovni sud FBiH odlučujući o spornom pravnom pitanju bavi se pravilnim tumačenjem i primjenom neodređene, neprecizne ili nejasne pravne norme da bi riješio dilemu prvostupanjskih sudova kako postupiti u konkretnoj pravnoj stvari kada ih prvostupanjski sudovi različito tumače, po pravilima postupka za usvajanje pravnih stavova, što znači da se ne radi o uspostavljanju percedenta. Ovdje se radi o specifičnom postupku koji se iz točno određenih zakonskih razloga može pokrenuti s ciljem da pruži pomoć prvostupanjskim sudovima u osiguranju standarda jednakosti, pravne sigurnosti i suđenja u razumnom roku, što je i sama svrha ovog instituta, a radi čega je u određenoj mjeri, ako i jeste, „opravdano“ žrtvovano načelo neovisnosti prvostupanjskih sudova.

\section{PRETHODNI POSTUPAK PRED EUROPSKIM SUDOM PRAVDE}

\subsection{Općenito o prethodnom postupku}

Europski sudski sustav se sastoji od dvije vrste sudova, onih koji su osnovani na razini Europske unije, te drugih, osnovanih na razini država članica. Njihov

\footnotetext{
$9 \quad$ Vidi Salma, o. c., str. 293.

10 Tako i Palačković, D., O nekim suštinskim novim rješenjima Zakona o parničnom postupku Republike Srpske, Pravni život, 2007., Tom V, str. 607.

11 Vidi Račić, R., Pravna priroda odlučivanja Vrhovnog suda u postupku za rješavanje spornog pravnog pitanja, Sudska praksa, Domaća i strana, god. XIII, br. 70, 2016., str. 14.
} 
međusobni odnos nije hijerarhijski, što znači da ne postoji žalbeni put kojim spor započet pred nacionalnim sudom može biti preispitan pred jednim od sudova EU-a. Osnovni put kroz koji je uspostavljena izravna komunikacija između nacionalnih sudova i Europskog suda pravde (dalje u tekstu: Sud) jest prethodni postupak za tumačenje ili ocjenu valjanosti prava EU. ${ }^{12}$ Tumačenja prava EU-a koja daju sudovi EU, posebice Sud, obvezujuća su za sve sudove u državama članicama.

Nacionalni sud koji nije siguran u ispravno tumačenje prava EU-a, jer ga u situaciji koju rješava, Sud, još nije dao ili ako nije siguran u ranije tumačenje Suda, posebice njegovu primjenu na novu situaciju, može pokrenuti pred Sudom prethodni postupak u kojem od tog Suda traži ispravno tumačenje norme prava EU-a koju treba primijeniti u svom predmetu. ${ }^{13}$ Prema tome, prethodni postupak omogućava bilo kojem sudu u bilo kojoj državi članici, tijekom bilo kojeg sudskog postupka u kojem se javlja određeno pitanje prava EU, da Sudu postavi pitanje o interpretaciji ili valjanosti pojedinih propisa prava EU-a. Smisao ovog postupka je osigurati ujednačeno tumačenje i primjenu prava EU-a. Osnovne odredbe o prethodnom postupku sadržane su u čl. 267. Ugovora o funkcioniranju Europske unije (UFEU), prema kojima je Sud nadležan odlučivati o prethodnim pitanjima koja se tiču:

a) tumačenja Ugovora (tzv. primarno pravo)

b) valjanosti i tumačenja akata institucija, tijela, ureda ili agencija Unije (tzv. sekundarno pravo, odnosno propisi doneseni na temelju pravne osnove sadržane u Ugovoru odnosno primarnom pravu). ${ }^{14}$ Dakle, u postupku prethodnog odlučivanja, Sud se može baviti pravilnim tumačenjem primarnog prava, ali ne i njegovom valjanošću, dok sekundarno pravo, poput direktiva i uredbi, može biti predmetom, kako odluke o tumačenju, tako i odluke o valjanosti. Samo je Sud nadležan odlučiti da je neka odredba sekundarnog prava EU-a nevaljana. Međutim, „sudovi u državama članicama mogu u povodu prigovora neke od stranaka zauzeti stajalište da je takva odredba valjana. Na nacionalnom sudu je da

12 Vidi Ćapeta, T., Sudski sustav Europske unije i njegov utjecaj na procesno pravo država članica, rad u knjizi: Babić, D. - Čulinović - Herc, E. - Garašić, J. - Goranić, I. - Grković, N. - Hau, W. - Kengyel, M. - Kunštek, E. -Lazić, V. - Martiny, D. - Meller, - Hannich, C. - Rivajec, V. - Sturner M., - Župan, M., Europsko građansko procesno pravo - Izabrane teme, Narodne novine Zagreb, 2013. (dalje - Ćapeta), str. 33. - 34.

Ibid.

Prethodni postupak je bio predviđen u originalnom Ugovoru o ekonomskoj zajednici u članku 177. Kasnije je on postao čl. 267 UEZ, a nakon izmjena koje je donio Lisabonski ugovor, danas je to čl. 267 UFEU. 
procjeni, imajući u vidu činjenice spora, potrebu za pokretanjem postupka za prethodno pitanje u svrhu rješenja spora. U ostvarivanju svoje ovlasti procjene, nacionalni sud u suradnji sa Sudom ispunjava dužnost koja im je dana, a to je da se osigura pravilna interpretacija i provođenje Ugovora." ${ }^{15}$ „Sud je koristeći se institutom prethodnog postupka postavio neke od temeljnih doktrina europskog prava kao što su doktrina izravnog učinka i načelo nadređenosti." ${ }^{16}$ Ova dva načela za sudove stvaraju obvezu koju je Sud objasnio i potvrdio ranije utvrđeno stajalište, u predmetu Simenthal ${ }^{17}$ gdje je naveo da u uvjetima kada su u istoj činjeničnoj situaciji primjenjive dvije norme, jedna europska i druga nacionalna, nacionalni sudac prednost u primjeni daje europskoj normi, ostavljajući na vlastitu inicijativu neprimijenjenom, ako smatra da je to potrebno, svaku suprotnu odredbu nacionalnog prava, čak i ako je ona donesena kasnije, bez potrebe da zatraži ili čeka prethodno stavljanje izvan snage te odredbe kroz zakonodavni ili bilo koji drugi postupak predviđen ustavom.

15 Vidi Šago, D., Postupak prethodnog odlučivanja pred Europskim sudom - problemi i moguća rješenja, Zbornik Pravnog fakulteta Sveučilišta u Rijeci, Vol 36, br. 1, 2015., (dalje - Šago), str. 384.

Tako i Čizmić. J., Komentar Zakona o parničnom postupku Federacije Bosne i Hercegovine, drugo izmijenjeno i dopunjeno izdanje, (dalje - Čizmić - Komentar), Sarajevo, 2016., str. 252. - 253.

Vidi Šago, o. c., str. 382.

Izravni učinak prava EU podrazumijeva da je norma prava EU (pod određenim uvjetima) sposobna izravno prodrijeti do svakog subjekta u nacionalnom pravnom sustavu. Stoga je njegova posljedica nastanak obveze nacionalnih sudova da prepoznaju subjektivno pravo koje takva norma dodjeljuje određenom subjektu. Vidi Ćapeta, o. c., str. 45.

Doktrina nadređenosti je nastala u sudskoj praksi Suda počevši s presudom Van Gend en Loos gdje je Sud postavio temelje načela nadređenosti prava EU nacionalnom pravu, objasnivši da Zajednica predstavlja novi pravni poredak međunarodnog prava u čiju su korist države ograničile svoja suverena prava i koja stvara subjektivna prava državama i građanima. Vidi presudu od 5. veljače 1963. godine, Van Gend en Loos v Nederlands Administratie der Belastingen, C26/62, EU:C: 1963:1.

Doktrinu nadređenosti Sud je dalje nadogradio presudom Costa v. ENEL, utvrdivši pravo prvenstva odnosno nadređenosti prava Zajednice u odnosu na nacionalno pravo, pa čak i u odnosu na kasnije donesene nacionalne propise u bilo kojem obliku. Vidi presudu od 15. srpnja 1964. godine, Flaminio Costa v. E.N.E.L., C 6/64, EU:C:1964:66.

Vidi presudu od 9. ožujka, Amministrazione delle Finanze dello Stato v. Simmenthal S.p.A., C 106/77, EU:C:1978:49 


\section{AKTIVNO LEGITIMIRANA TIJELA ZA PODNOŠENJE ZAHTJEVA}

Prethodni postupak pred Sudom mogu pokrenuti samo nacionalni sudovi. Bilo koji nacionalni sud može pokrenuti prethodni postupak ako mu je tumačenje prava EU-a nužno za donošenje odluke u konkretnom predmetu. „Sudovi prethodni postupak pokreću po službenoj dužnosti (ex offo), što znači da ne mora postojati istaknuti prigovor ili prijedlog stranke za pokretanjem prethodnog postupka." ${ }^{18}$ Vrlo je važno pitanje što neko tijelo čini sudom kako bi Sud mogao biti nadležan odgovoriti na njegovo pitanje. ${ }^{19}$ Odredba 267. UFEU čini se jasnom, radi se o sudu ili sudskim tijelima. Međutim, ta definicija ne ovisi o nacionalnom, već o pravu EU-a. „Po pitanju što neko tijelo čini sudom Sud je dao odgovor u predmetu Dorsch Consult, ${ }^{20}$ gdje je kao mjerodavne kriterije takvog tijela naveo: da je tijelo uspostavljeno zakonom odnosno javnim pravom, da je stalno, da ima obveznu nadležnost, odlučuje inter partes, da primjenjuje pravna pravila, te da je neovisno u svom radu. “21

\subsection{Ovlaštenje i dužnost postavljanja prethodnog pitanja}

Ugovor u čl. 267. UFEU pravi razliku između sudova koji mogu i koji moraju uputiti prethodno pitanje Sudu. Tako u situaciji kada se takvo pitanje postavi pred bilo kojim sudom države članice taj sud može, ako smatra da mu je odluka o pitanju nužna da bi presudio, zatražiti od Suda da o tome odluči. ${ }^{22}$ Dakle, ovi sudovi imaju ovlast pokrenuti prethodni postupak. Za razliku od njih, kada se takvo pitanje postavi u predmetu koji teče pred sudom države članice protiv čijih odluka nema pravnog lijeka na temelju nacionalnog prava, taj sud mora uputiti predmet Sudu. ${ }^{23}$ Dakle, pokretanje prethodnog postupka je njihovo, ne samo ovlaštenje, već i obveza. Ako se takvo pitanje postavi u predmetu koji teče pred sudom države članice u vezi s osobom u pritvoru, Sud će postupati u najkraćem mogućem vremenu. ${ }^{24}$

$18 \quad$ Vidi Šago, o. c., str. 386.

19 Vidi Matija, M., Prethodni postupak pred Europskim sudom: opći pregled, rad u knjizi: Prethodni postupak u pravu Europske unije, suradnja nacionalnih sudova s europskim sudom, urednici Ćapeta, T., Glodner Lang, I., Perišin, T., Rodin, S., Narodne novine Zagreb, 2011., str. 18. - 20.

Vidi presudu od 17. rujna 1997. godine, Dorch Consult, C-54/96, EU:C:1997:413.

Vidi Šago, o. c., str. 384.

Čl. 267., st. 2. UFEU.

Čl. 267. st. 3. UFEU.

Čl. 267. st. 4. UFEU. 


\subsection{Izuzeci od obveze upućivanja zahtjeva}

Kao što je naprijed navedeno, nacionalni sudovi nižih instanci imaju diskrecijsku ovlast uputiti pitanja Sudu, dok su sudovi najviše instance dužni uputiti pitanja ako je pravo EU-a relevantno za rješavanje nekog konkretnog predmeta. Međutim, u odnosu na obvezu upućivanja zahtjeva postoje dvije iznimke. Doktrina acte éclairé (doktrina presedana) dopušta izuzimanje od obveze upućivanja zahtjeva suda najviše instance u situaciji kada već postoji prethodna odluka Suda o istoj stvari. Ovu doktrinu Sud je objasnio u predmetu $\mathrm{Da}$ Costa $^{25}$ gdje je utvrdio: „Premda čl. 234. UEZ bezrezervno zahtijeva od nacionalnog suda ili tribunala protiv čijih odluka nema prava žalbe da upute Sudu svako pitanje tumačenja koje se pred njim pojavi, autoritet ranije odluke suda može lišiti te obveze. To je naročito u slučaju ako su pitanja identična sa onima koja su već bila predmetom prethodnog postupka i o kojima je Sud već donio svoju odluku, bez obzira na vrstu postupka, pa čak i ako pitanja nisu potpuno ista." Na ovaj način Sud je omogućio nacionalnim sudovima najviših instanci da se pouzdaju u njegove prethodne odluke u slučaju kada se postavlja isto pitanje. ${ }^{26}$

Doktrina acte clair oslobađa nacionalni sud najviše instance (čl. 267. st. 3. UFEU) obveze da uputi pitanje ako je odgovor očit pa čak i u situaciji kada ne postoji ranija odluka Suda o tom pitanju. Ovu doktrinu Sud je prvi put upotrijebio i priznao u predmetu Cilfit ${ }^{27}$ gdje je zauzeo stajalište da nacionalni sud ne mora postaviti pitanje u slučajevima kada je ispravna interpretacija europskog prava tako očita da ne postoji osnovana sumnja o tome kako bi se taj predmet trebao riješiti. U suštini, sudovi, protiv čijih odluka nema pravnog lijeka prema nacionalnom pravu, u pravilu su obvezni podnijeti pitanja tumačenja ili ocjene valjanosti Sudu osim ako zaključe: da je pravo Unije irelevantno za spor, da je Sud već odlučio o tome, te ako je ispravno tumačenje pravila prava Unije toliko očito da ne ostavlja mjesta razumnoj sumnji.

25 Vidi presudu od 27. ožujka 1963. godine, Da Costa en Scahaake NV, Jacob Meijer NV and Hoechst - Holand NV v. Nederlandese Belastingadministratie, C 28 - 30/62, EU:C:1963:6. Vidi Šago, o. c., str. 387.

U predmetu Cilfit sud je utvrdio: (...) da bi zaključio da je pravilna primjena prava Zajednice tako očita da ne postoji utemeljena sumnja glede odgovora na eventualno pitanje, nacionalni sud mora biti siguran da je odgovor jednako očit sudovima u drugim državama članicama i Sudu. Nacionalni sud mora biti svjestan da se zakonodavstvo Zajednice objavljuje na svim službenim jezicima i da su sve verzije autentične, nadalje mora biti svjestan da pravo zajednice upotrebljava vlastitu terminologiju u kojoj određeni pojmovi nemaju isto značenje koje imaju u pravnom sustavu države članice. Svaku odredbu treba smjestiti u konkretni kontekst i u okviru prava zajednice u cijelosti imajući u vidu ciljeve Zajednice i stupanj razvoja u danom trenutku. Vidi presudu od 6. listopada 1982. godine, Cilfit $v$ Ministry of health, C-283/91, EU:C:1982:335. 


\section{OBLIK I SADRŽAJ ZAHTJEVA ZA PRETHODNU ODLUKU}

Sam Ugovor, kao ni Statut Suda i Pravila postupka ne propisuju formu u kojoj mora biti podnesen zahtjev za prethodnu odluku. ${ }^{28}$ Sud je u Preporuci ${ }^{29}$ nacionalnim sudovima rekao da zahtjev za prethodnu odluku može imati bilo koji oblik dopušten nacionalnim postupovnim pravilima. Što se tiče samog sadržaja, treba imati u vidu da taj zahtjev služi kao osnova postupka pred Sudom i da se dostavlja svim zainteresiranim osobama iz čl. 23. Protokola br. 3. Statuta, ${ }^{30}$ te osobito svim državama članicama kako bi se prikupila njihova eventualna očitovanja. Kako se zahtjev za prethodnu odluku mora prevesti na sve službene jezike Europske unije, preporučuje se da jezik nacionalnog suda bude jednostavan, jasan i precizan, bez suvišnih elemenata. Zahtjev treba biti kratak, ali dovoljan opsežan, da bi sadržao sve relevantne informacije da se Sudu i strankama koje su ovlaštene podnijeti svoja očitovanja omogući dovoljno jasno shvaćanje činjeničnog i pravnog stanja u glavnom postupku. U tom smislu preporučuje se maksimum od desetak stranica. ${ }^{31} \mathrm{Uz}$ tekst samih prethodnih pitanja postavljenih Sudu, zahtjev za prethodnu odluku mora sadržavati: sažet prikaz predmeta spora i relevantne činjenice kako ih je utvrdio sud koji upućuje zahtjev ili barem prikaz činjeničnih okolnosti na kojima se temelje pitanja, sadržaj nacionalnih odredbi koje se mogu primijeniti u predmetu i relevantnu nacionalnu sudsku praksu, kao i prikaz razloga koji su naveli sud koji upućuje zahtjev da se zapita o tumačenju ili valjanosti određenih odredaba prava Unije, kao i pojašnjenje veze koja prema mišljenju tog suda postoji između tih odredaba i nacionalnog zakonodavstva primjenjivog u glavnom postupku. ${ }^{32} \mathrm{U}$ slučaju nedostatka jednog od pobrojanih elemenata ili više njih, Sud će se proglasiti nenadležnim za odlučivanje o postavljenim prethodnim pitanjima ili odbaciti zahtjev za prethodnu odluku kao nedopušten. I kroz praksu Suda razvila su se određena ograničenja dopustivosti

Tako je već u prvom zahtjevu za prethodno pitanje Sud izrijekom utvrdio da Ugovor ne propisuje formu akta (odluke) kojom nacionalni sud postavlja pitanje. Vidi presudu od 6. travnja 1962. godine, De Geus v. Bosch, C- 13/61 EU:C:1962:11. Nakon toga je to potvrdio i u svojim kasnijim odlukama. Vidi presudu od 28. lipnja 2007. godine, Dell 'Orto, C-467/05, EU:C:2007:395, i presudu od 12. kolovoza 2008. godine, Santesteban Goicoechea, C-296/08 PPU, EU:C:2008:457.

Preporuke namijenjene nacionalnim sudovima koje se odnose na pokretanje prethodnog postupka br. 2018/C 257/01, dostupno na: https://eur-lex.europa.eu/legal-ontent/HR/ TXT/PDF/?uri=CELEX:32018H0720(01)\&from (dalje - Preporuka).

Statut suda Europske unije, (dalje - Statut), dostupno na: https://curia.europa.eu/jcms/ upload/docs/application/pdf/2016-08/tra-doc-hr-div-c-0000-2016-201606984-05_00.pdf Vidi t. 14. Preporuke.

32 Vidi t. 15. Preporuke. 
prethodnog pitanja. Radi se o slučajevima kad nacionalni sud u zahtjevu nije opisao činjenice predmeta i relevantno nacionalno pravo ("pravna i činjenična pozadina spora") dovoljno jasno da bi Sud dao koristan odgovor, ${ }^{33}$ odnosno kad je pitanje koje je nacionalni sud postavio hipotetsko ili kad je interpretacija koju nacionalni sud traži očito nepovezana s činjenicama ili smislom predmeta koji je pred njime. ${ }^{34}$

Čl. 267. UFEU, kao niti Statut i Poslovnik ne određuju trenutak kada treba uputiti zahtjev. Nacionalni sud može uputiti zahtjev za prethodnu odluku čim utvrdi da mu je za donošenje presude potrebna odluka o tumačenju ili valjanosti prava. Međutim, na nacionalnom sudu je da sam procijeni u kojem je stadiju postupka najprikladnije da to učini, ${ }^{35}$ što je Sud potvrdio i u svojim odlukama. ${ }^{36}$ Dakle, u pravilu Sud ne ulazi u diskrecijsku ovlast nacionalnog suda (izuzev ako je zahtjev preuranjen) kod procjene najprikladnijeg trenutka za upućivanje zahtjeva, ali kod činjenice da će taj zahtjev poslužiti kao osnova postupka koji će se voditi pred Sudom i da on mora imati na raspolaganju sve elemente potrebne za donošenja odluke potrebno je da se odluka o upućivanju zahtjeva donese u stadiju postupka u kojem sud koji upućuje zahtjev može dovoljno precizno utvrditi pravni i činjenični okvir glavnog postupka te pravna pitanja koja iz njega proizlaze, čime je ipak, donekle, ograničena njegova diskrecija u pogledu stadija u kojem uputiti pitanje. Također se preporučuje da se pitanje uputi nakon održane kontradiktorne rasprave. ${ }^{37}$ Ako nacionalni sud nije u dovoljnoj mjeri utvrdio pravno i činjenično stanje, Sud može odbaciti takav zahtjev. ${ }^{38}$

33 Tako je u predmetu Lehtonen Sud prihvatio odgovoriti na pitanja koja su se ticala odredaba Ugovora o tržišnim slobodama, no ne i na pitanja o primjeni odredaba o tržišnom natjecanju, jer je smatrao da nema dovoljno podataka za davanje korisnog odgovora o tom pitanju. Vidi presudu od 12. travnja 2000. godine, Lehtonen, C-176/96 EU:C:2000:20.

Tako je u spojenim predmetima Aziz Melki i Sélim Abdeli Sud utvrdio da može odbiti odlučiti o pitanju koje je uputio nacionalni sud samo ako je sasvim očigledno da traženo tumačenje prava EU nema veze sa stvarnim činjenicama predmeta ili njegovom svrhom, ako je problem hipotetički, ili ako Sud nema činjenični ili pravni materijal potreban za koristan odgovor na pitanja koja su mu postavljena. Vidi presudu od 22. lipnja 2010. godine, Aziz Melki i Sélim Abdeli, C-188/10 i C-189/10, EU:C:2010:363. Vidi t. 12. Preporuke.

Vidi presudu od 21. travnja 1988. godine, Pardini, C-338/85, EU:C:1988:194. Vidi t. 13. Preporuke.

Tako je Europski sud u spojenim predmetima Telemarsicabruzzo SpA v. Circostel, Ministero delle Poste e Telecommunicazioni i Ministero della Difesa, Telaltitalia Srl v. Circostel, Ministero delle Poste e Telecommunicazioni i Ministero della Difesa, i Telelazio SpA v. Circostel, Ministero delle Poste e Telecommunicazioni i Ministero della Difesa odlučio da iako ako su mu dostavljene neke informacije iz spisa koje je dostavio nacionalni sud, što je vidljivo iz 


\section{ODNOS IZMEĐU PRETHODNOG POSTUPKA I NACIONALNOG POSTUPKA}

Prethodni postupak se odvija u dvije faze. Prva je ona pred nacionalnim sudom prilikom odluke o upućivanju prethodnog pitanja, a druga pred Sudom prilikom donošenja odluke o istom. ${ }^{39}$ Do donošenja odluke Suda postupak pred nacionalnim sudom se prekida. Kako prethodni postupak pretpostavlja da je spor stvarno u tijeku pred sudom koji upućuje zahtjev, dužnost je nacionalnog suda obavijestiti Sud o svakoj postupovnoj okolnosti koja dovodi do okončanja postupka (npr. o povlačenju tužbe, mirnom rješenju spora i sl.). Također, u obvezi je obavijestiti Sud o eventualnom donošenju odluke povodom žalbe protiv odluke kojom se upućuje zahtjev i o posljedicama koje ona ima na zahtjev za prethodnu odluku. Od velike je važnosti da se te informacije dostave u najkraćem mogućem roku u interesu dobrog odvijanja prethodnog postupka pred Sudom. Isto tako nacionalnim sudovima je skrenuta pozornost na činjenicu da povlačenje zahtjeva za prethodnu odluku može imati utjecaj na vođenje sličnih postupaka (ili niza postupaka) suda koji upućuje zahtjev. Stoga je korisno da nacionalni sud, u situaciji kad ishod nekoliko predmeta u tijeku pred njim ovisi o odgovoru na pitanja koji će dati Sud, sve te predmete spoji u zahtjeve za prethodnu odluku kako bi Sudu omogućio odgovaranje na postavljena pitanja unatoč eventualnom okončanju jednog predmeta ili više njih. ${ }^{40}$

\section{ODLUKE SUDA U PRETHODNOM POSTUPKU}

Odluke Suda imaju izravan učinak u državama članicama, čime se u pravnom sustavu EU-a osigurava ujednačenost prava. ${ }^{41} \mathrm{U}$ postupku po prethodnom

zapisnika o saslušanju i usmenih očitovanja stranaka na raspravi, te su informacije nedovoljne i ne dopuštaju Sudu da zbog nedovoljnog znanja o činjenicama u glavnom postupku tumači pravila tržišnog natjecanja Zajednice u svjetlu sporne situacije, kako je to zatražio nacionalni sudac, radi čega je odlučio da nema potrebe donositi odluku o pitanjima koja je postavio gosp. Vice Pretore iz Frascatija. Vidi presudu od 26. siječnja 1993. godine, Telemarsicabruzzo SpA v. Circostel, Ministero delle Poste e Telecommunicazioni i Ministero della Difesa, Telaltitalia Srl v. Circostel, Ministero delle Poste e Telecommunicazioni i Ministero della Difesa, i Telelazio SpA v. Circostel, Ministero delle Poste e Telecommunicazioni i Ministero della Difesa, C-320/90, C-321/90 i C-322/90, EU:C:1993:26.

Tako i Petrašević, T., Prethodni postupak pred Europskim sudom pravde i njegova implementacija u hrvatsko procesno pravo, Godišnjak Akademije pravnih znanosti Hrvatske, Vol. V No. 1, 2014., str. 5.

Vidi t. 23., 24. i 25. Preporuke.

$41 \quad$ Vidi Šago, o. c., str. 396. 
pitanju Sud može donijeti dvije vrste odluka, presudu ili rješenje. U najvećem broju pitanja Sud odlučuje presudom sukladno odredbama Statuta i Poslovnika, ali je moguće da odluči i obrazloženim rješenjem. To će biti u slučaju pojednostavljenog prethodnog postupka. Odluke imaju svojevrsni erga omnes učinak jer djeluju za sve sudove u Zajednici. ${ }^{42}$ Po pitanju vremenskog važenja interpretativnih odluka, odnosno presuda o tumačenju prava, Sud je kroz svoju praksu zaključio da one stupaju na snagu od dana kada je tumačeno pravilo stupilo na snagu, ${ }^{43}$ da su takve odluke deklaratorne i djeluju ex tunc (retroaktivno). ${ }^{44}$ Pravna pravila Europske unije nacionalni sudovi moraju primijeniti na način na koji su bila protumačena čak i na pravne odnose koji su nastali i koji su uspostavljeni prije donošenja interpretativne presude. ${ }^{45}$ Premda interpretativne presude Suda imaju povratno djelovanje, one ipak ne utječu na pravno pravilo presuđene stvari (res iudicata), pa je stoga važno da sve nacionalne sudske odluke koje su postale pravomoćne, nakon što su iskorišteni svi pravni lijekovi ili nakon isteka predviđenih rokova, više ne mogu biti dovedene u pitanje. ${ }^{46}$

Sam postupak pred Sudom se ne naplaćuje. O troškovima stranaka u postupku Sud ne odlučuje već nacionalni sudovi u skladu s pravilima o uspjehu u parnici (pravilo causae). ${ }^{47}$

42 Vidi Goldner Lang, I., Učinci presuda Europskog suda u prethodnom postupku, rad u knjizi: Prethodni postupak u pravu Europske unije, suradnja nacionalnih sudova sa Europskim sudom, urednici Ćapeta, T., Goldner Lang, I., Perišin, T., Rodin, S., Narodne novine, Zagreb, 2011., str. 89. - 93. Vidi presudu od 19. listopada 1995. godine, Richardson, C- 137/94, EU:C:1995:342. Vidi presudu od 12. veljače 2008. godine, Willy Kempter KG protiv Hauptzollamt Hamburg-Jonas, C-2/06, EU:C:2008:78.

Vidi presudu od 3. listopada 2002. godine, Angel Barreira Pérez v. Instituto Nacional de la Seguridad Social (INSS), Tesorería General de la Seguridad Social, C-347/00, EU:C:2002:560, presudu od 27. ožujka 1980. godine, Amministrazione delle finanze dello Stato $v$ Denkavit italiana, C-61/79, EU:C:1980:100.

Vidi presudu od 13. siječnja 2004. godine, Kühne \& Heitz NV v. Produktschap voor Pluimvee en Eieren, C-453/00, EU:C:2004:17.

Budući da se ovaj postupak gleda samo kao korak u postupku pred nacionalnim sudovima, o troškovima upućivanja prethodnog pitanja Europskom sudu pravde odlučuje nacionalni sud, odlučujući o troškovima glavnog postupka. Za razliku od presuda po direktnim tužbama, Sud ne odlučuje o troškovima postupka. Ovakav stav prvi put je iskazan u predmetu De Geus v. Bosch (Vidi presudu od 6. travnja 1962. godine, Kledingverkoopbedrijf de Geus en Uitdenbogerd $v$ Robert Bosch GmbH and Maatschappijtot voortzetting van de zaken der Firma Willem van Rijn, C 13/61 EU:C:1962:11), a potom je unesen u čl. 104. st. 6. Poslovnika Suda. Podatak kod Šago, o. c., str. 396. 
KEVO, M., BELOVIĆ, M., Postupak za rješavanje spornog pravnog pitanja s osvrtom na prethodni postupak pred... Zbornik radova Pravnog fakulteta Sveučilišta u Mostaru, br. XXIX., 2021., str. 42. - 67.

\section{POSTUPAK ZA RJEŠAVANJE SPORNOG PRAVNOG PITANJA U BOSANSKOHERCEGOVAČKOM ZAKONODAVSTVU}

\subsection{Uvjeti za pokretanje postupka za rješavanje spornog pravnog pitanja}

Odredbom čl. 61a st. 1. Zakona o parničnom postupku Federacije $\mathrm{BiH}^{48}$ propisane su procesno pravne pretpostavke, odnosno uvjeti koji moraju biti ispunjeni, da bi prvostupanjski sud mogao pokrenuti postupak za rješavanje spornog pravnog pitanja pred Vrhovnim sudom $\mathrm{FBiH}^{49}$ To su: da postoji sporno pravno

$48 \quad$ Zakon o parničnom postupku Federacije Bosne i Hercegovine, Službene novine Federacije Bosne i Hercegovine br. 53/03., 73/05., 19/06. i 98/15. - dalje, ZPP FBiH

Ovaj postupak u Republici Hrvatskoj nosi naziv Ogledni postupak, a uveden je posljednjom reformom parničnog procesnog prava iz 2019. godine odnosno Zakonom o izmjenama i dopunama Zakona o parničnom postupku, „Narodne novine“ br. 70/2019. Iza članka 502.h Zakona o parničnom postupku Republike Hrvatske („Narodne novine“ br. 53/1991, 91/1992, 112/1999, 88/2001, 117/2003, 88/2005, 2/2007, 84/2008, 96/2008, 123/2008, 57/2011, 148/2011, 25/2013, 89/2014 i 70/2019 - dalje ZPP RH) dodana je nova glava 32. b i članci 502.i do 502.n, koja nosi naziv Ogledni postupak radi rješenja pitanja važnog za jedinstvenu primjenu prava, koji se primjenjuje u postupcima u kojima odluka ovisi o rješavanju istog pravnog pitanja (čl. 502.i ZPP RH). Postupci u kojima odluka ovisi o rješavanju istog pravnog pitanja prema odredbama ove glave su slični sporovi koji su u većem broju već pokrenuti ili se njihovo pokretanje očekuje u kraćem razdoblju, a rješenje kojih ovisi o istom pravnom pitanju koje je važno za osiguranje jedinstvene primjene prava i ravnopravnosti svih u njegovoj primjeni ili za razvoj prava kroz sudsku praksu - pitanju važnom za jedinstvenu primjenu prava (čl. 502.j ZID ZPP RH). Ogledni postupak pokreće prvostupanjski sud, koji će nakon održavanja pripremnog ročišta i sjednice sudskog odjela dostaviti prijedlog za rješenje pitanja važnog za jedinstvenu primjenu prava sa spisom predmeta Vrhovnom sudu Republike Hrvatske radi zauzimanja pravnog shvaćanja o tom pitanju. Predsjednik Vrhovnog suda Republike Hrvatske nakon primitka prijedloga za rješenje pitanja važnog za jedinstvenu primjenu prava bez odgode traži od predsjednika svih prvostupanjskih sudova da ga obavijeste o tome jesu li i u kojem broju pred njihovim sudovima pokrenuti takvi sporovi, a isti su ove podatke dužni dostaviti predsjedniku Vrhovnog suda Republike Hrvatske u roku od 15 dana (čl. 502. 1. ZPP RH). U prijedlogu prvostupanjski sud mora određeno naznačiti pravno pitanje o kojemu predlaže zauzimanje pravnog shvaćanja Vrhovnog suda Republike Hrvatske te određeno izložiti razloge zbog kojih smatra da je ono važno. O dopuštenosti prijedloga za rješenje pitanja važnog za jedinstvenu primjenu prava odlučuje vijeće od pet sudaca Vrhovnog suda Republike Hrvatske rješenjem u roku od 30 dana od isteka roka od 15 dana za dostavljanje podataka Vrhovnom sudu od predsjednika prvostupanjskih sudova. U odluci kojom se prijedlog odbija dovoljno je da se Vrhovni sud Republike Hrvatske pozove na nedostatak pretpostavki za podnošenje prijedloga. Rješenje o odbijanju prijedloga će odmah objaviti na mrežnoj stranici e-oglasna ploča sudova. Prvostupanjski sud će nakon objave tog rješenja nastaviti postupak po odredbama koje se na njega inače primjenjuju. 
U odluci kojom se dopušta prijedlog Vrhovni sud Republike Hrvatske navodi u kojem dijelu i u odnosu na koje određeno pravno pitanje dopušta zauzimanje pravnog shvaćanja. Rješenje kojim dopušta prijedlog će odmah objaviti na mrežnoj stranici e-oglasna ploča sudova. Protiv rješenja povodom prijedloga pravni lijek nije dopušten (čl. 502. lj. ZPP RH). O pitanju važnom za jedinstvenu primjenu prava odlučuje vijeće od pet sudaca Vrhovnog suda Republike Hrvatske rješenjem u roku od 90 dana od dana objave rješenja kojim je dopušten prijedlog. Rješenje će se odmah objaviti na mrežnoj stranici e-oglasna ploča sudova (čl. 502. m ZPP RH). Nakon donošenja pravnog shvaćanja Vrhovnog suda Republike Hrvatske sud će u nastavljenim postupcima biti vezan tim pravnim shvaćanjem (čl. 502. n). O oglednom postupku detaljnije kod Uzelac, A., Ogledni postupak radi rješenja pitanja važnog za jedinstvenu primjenu prava: dobre strane i problematični elementi novog instrumenta, Zbornik radova s VI. međunarodnog savjetovanja „Aktualnosti građanskog procesnog prava - nacionalna i usporedna pravnoteorijska i praktična dostignuća“, str. 19. - 38., preuzeto s: http://www.alanuzelac.from.hr/pubs/A71-Uzelac_Ogledni\%20postupak_Split.pdf

Maganić, A., Ogledni postupak ili postupak za rješavanje spornog pravnog pitanja, Revija Kopaoničke škole prirodnog prava, 1, 2019., str. 219. - 236. U Republici Srbiji postupak za rješavanje spornog pravnog pitanja uveden je u parnični postupak Zakonom o parničnom postupku Srbije iz 2004. godine. Ovim zakonom je bilo određeno da ako u postupku pred prvostupanjskim sudom u većem broju predmeta postoji potreba da se zauzme stav o spornom pravnom pitanju koje je od prejudicijalnog značaja za odlučivanje o predmetu postupka pred prvostupanjskim sudovima, prvostupanjski sud će po službenoj dužnosti ili na prijedlog stranke, zahtjevom pokrenuti postupak pred Vrhovnim kasacionim sudom radi rješavanja spornog pravnog pitanja. Sud koji je pokrenuo postupak za rješavanje spornog pravnog pitanja bio je dužan da zastane s postupkom dok se ne okonča postupak pred Vrhovnim kasacionim sudom (čl. 176. Zakona o parničnom postupku Republike Srbije, „Službeni glasnik“, br. 125/04 - dalje ZPP Srbije 2004). Zahtjev je trebao sadržavati kratak prikaz utvrđenog stanja stvari u konkretnoj pravnoj stvari, navode stranaka o spornom pravnom pitanju i razloge zbog kojih se sud obraća sa zahtjevom za rješavanje spornog pravnog pitanja. Sud je uz zahtjev mogao priložiti i vlastito tumačenje spornog pravnog pitanja (čl. 177. ZPP Srbije 2004). Sud koji je pokrenuo postupak za rješavanje spornog pravnog pitanja dužan je da zastane s postupkom dok se ne okonča postupak pred Vrhovnim kasacionim sudom (čl. 176. st. 2. ZPP Srbije 2004). Ako zahtjev nije sadržavao propisani sadržaj Vrhovni kasacioni sud bi odbacio zahtjev kao nepotpun, a kao nedozvoljen ako je o takvom zahtjevu Vrhovni kasacioni sud već donio odluku. Ako odluči da rješava sporno pravno pitanje, Vrhovni kasacioni sud odluku donosi po pravilima postupka za usvajanje pravnih stavova u roku od 90 dana od dana prijema zahtjeva, ako ono nije bilo od značaja za odlučivanje u većem broju predmeta, odbit će da zauzme stav o spornom pravnom pitanju (čl. 178. ZPP Srbije 2004). U pravnom shvaćanju koje je zauzeo u povodu zahtjeva za rješavanje spornog pravnog pitanja Vrhovni sud je razmatrao sporno pravno pitanje i navodio razloge kojima je obrazlagao svoju odluku. Pravno shvaćanje dostavljalo se sudu koji je zahtjev postavio i objavljivalo u Biltenu Vrhovnog suda Srbije (čl. 179., st. 2. ZPP Srbije 2004). Stranke u postupku u kojem se postavljalo isto sporno pravno pitanje nisu imale pravo da ponovno traže njegovo rješavanje u parnici koja je u tijeku (čl. 180. ZPP Srbije 2004). Zakonom o parničnom postupku Republike Srbije iz 2011. („Službe- 
pitanje, da je od značaja za odlučivanje u postupku pred prvostupanjskim sudom, i da se pojavljuje u većem broju predmeta. ${ }^{50}$ Ovi su uvjeti u svim procesnim zakonima u BiH kumulativno propisani, što znači da moraju svi zajedno biti ispunjeni.

\subsubsection{Sporno pravno pitanje}

Prvi uvjet koji treba biti ispunjen da bi prvostupanjski sud mogao pokrenuti postupak za rješavanje spornog pravnog pitanja pred Vrhovnim sudom $\mathrm{FBiH}$ jeste da postoji sporno pravno pitanje. Sam zakon ne daje definiciju spornog pravnog pitanja, ali se u teoriji ono definira kao sporno pitanje o pravnom značenju pravne norme, bilo materijalne, bilo procesne, koja treba da se primjeni na konkretno činjenično stanje. Riječ je o tumačenju prava radi njegove primjene..$^{51}$ Ako bi se zahtjevom tražila primjena materijalnog prava na konkretno činjenično stanje, a ne pravilno tumačenje i primjena neodređene, neprecizne ili nejasne pravne norme Vrhovni sud FBiH odbit će zahtjev za rješavanje spornog pravnog pitanja. ${ }^{52} \mathrm{Da}$ bi

ni glasnik“, br. 72/2011) unesene su određene izmjene u odredbe postupka za rješavanje spornog pravog pitanja koji je sada uređen odredbama čl. 180-185. Zakon o parničnom postupku Srbije („Službeni glasnik“, br. 72/2011, 49/2013 - odluka US, 74/2013 - odluka US, 55/2014, 87/2018 i 18/2020 - dalje ZPP Srbije). Tako je u usporedbi s ranijim rješenjima izostala potreba da sporno pravno pitanje bude od prejudicijelnog značaja za odlučivanje u postupku pred prvostupanjskim sudovima (čl. 180, st. 1. ZPP Srbije). Nadalje, prvostupanjski sud nema više samo mogućnost, već dužnost da u zahtjevu za rješavanje spornog pravnog pitanja iznese vlastito tumačenje spornog pravnog pitanja, s tim da se zahtjev za rješenje spornog pravnog pitanja ne dostavlja strankama na izjašnjavanje (čl. 181, st. 1. ZPP Srbije). Međutim, ako stranka predloži pokretanje postupka za rješavanje spornog pravnog pitanja, sud može dostaviti prijedlog drugoj stranci radi izjašnjavanja u roku od 15 dana od dana dostavljanja prijedloga (čl. 181., st. 2. ZPP Srbije). Skraćen je i rok za rješavanje spornog pravnog pitanja na 60 dana, koji je ranije iznosio do 90 dana (čl. 183., st. 3. ZPP Srbije). I sljedeća izmjena tiče se objave odluke o spornom pravnom Vrhovnog kasacionog suda, tako da se sada prema čl. 184., st. 2. ZPP Srbije objavljuje na internetskoj stranici Vrhovnog kasacionog suda ili na drugi pogodan način, a ne više u Biltenu Vrhovnog kasacionog suda Srbije.

Istovjetene su odredbe čl. 61a st. 1. Zakon o parničnom postupku Republike Srpske, Službeni glasnik Republike Srpske, br. 58/2003., 85/03., 74/05., 63/07., 105/08., odluka US 45/09., odluka US 49/09. i 6/13. - dalje - ZPP RS, te čl. 161. ZPP BD.

Vidi Popović, V., Postupak za rješavanje spornog pravnog pitanja, preuzeto s: http:// www.vk.sud.rs/ sites/default/files/attachments/POSTUPAK\%20ZA\%20RE\%C5\%A0AVANJE\%20SPORNOG\%20 PRAVNOG\%20PITANJA\%20-V.Popovi\%C4\%87.pdf, (dalje - Popović), str. 3. vni stav koji glasi: "Kada se u vezi sa zahtjevom za rješavanje spornog pravnog pitanja 
Vrhovni sud FBiH odlučivao o pravnom pitanju kao spornom, sudska praksa pred prvostupanjskim sudovima o tom pitanju treba da bude različita povodom drugih „istih“ slučajeva, odnosno slučajeva, koji su „isti“ sa slučajem za koji se traži prethodni pravni stav Vrhovnog suda FBiH. Samo u onim slučajevima kada je sudska praksa različita, nužno je da reagira Vrhovni sud FBiH donošenjem odluke o spornom pravnom pitanju radi jednakosti, pravne sigurnosti i suđenja u razumnom roku. U protivnom, ako je sudska praksa o tom pitanju ujednačena, Vrhovni sud FBiH odbit će zahtjev za rješavanje spornog pravnog pitanja. ${ }^{53}$ Ono što je važno naglasiti je to da sudska praksa mora biti različita pred prvostupanjskim sudovima, što znači da je isključena mogućnost da se prvostupanjski sud obraća sa zahtjevom i inicira postupak rješavanja spornog pravnog pitanja zbog neslaganja s odlukom županijskog suda u kojoj je ovaj nakon žalbenog postupka izrazio svoje stanovište o spornom pravnom pitanju. ${ }^{54}$

Pitanje koje prvostupanjski sud istakne u zahtjevu kao sporno mora biti definirano na jasan i nedvosmislen način, a ne da se njegov smisao i značaj ocjenjuje na osnovu sadržaja zahtjeva i stanja u spisu. Ako pitanje ne bude tako određeno, Vrhovni sud $\mathrm{FBiH}$ odbacit će zahtjev za rješavanje spornog pravnog pitanja kao nepotpun. ${ }^{55}$ Ono ne može biti postavljeno hipotetički ${ }^{56}$ i mora biti sporno sudu a ne strankama. ${ }^{57}$ Ako sam prvostupanjski sud smatra da postavljeno sporno pravno pitanje

zaključi da se radi o primjeni materijalnog prava na konkretno činjenično stanje, te da se ne radi o tumačenju pravne norme kao neodređene, neprecizne ili nejasne, zahtjev treba odbiti temeljem odredbe čl. 61 d st. 2. ZPP - a F BiH. "Vidi Odluku Vrhovnog suda FBiH br. 682 Rs 01929219 Spp od 10. 7. 2019. godine. Pogledaj i Odluke Vrhovnog suda FBiH br. 560 Rs 06097218 Spp od 19. 10. 2018. godine, 320 Ps 14764618 Spp 2 od 19. 10. 2018. godine, 170 St 09020118 Spp od 20. 2. 2019. godine. Vidi Odluku Vrhovnog suda FBiH br. 510 Rs 06853216 Spp od 13. 7. 2017. godine. Tako je u Odluci br. 650 I 40910719 Spp Vrhovni sud FBiH naveo da je na sjednici građanskog odjeljenja od 31. 5. 2018. godine zauzeo pravni stav koji glasi: „Kada se općinski sud ne slaže sa odlukom županijskog suda u kojoj je nakon žalbenog postupka županijski sud izrazio svoje stanovište po navedenom spornom pravnom pitanju, takav zahtjev za rješavanje spornog pravnog pitanja treba odbaciti kao nedozvoljen na temelju čl. 61c. st. 1. ZPP-a F BiH.“ Vidi Odluku Vrhovnog suda FBiH br. 65 O I 40910719 Spp od 12. 6. 2019. godine.

55 Vidi Odluku Vrhovnog suda FBiH br. 650 I 54221716 Spp od 9. 6. 2016. godine. Pogledaj i Odluke Vrhovnog suda FBiH br. 530 Rs 06084316 Spp od 13. 6. 2016. godine, 430 St 13351817 Spp od 7. 4. 2017. godine, 682 Mal 01208517 Spp od 18. 10. 2017. godine, 180 V 03120318 Spp od 20.7.2018. godine.

Vidi Odluke Vrhovnog suda FBiH br. 682 Ip 01592618 Spp od 25. 4. 2048. i 1260 Ip 03840018 Spp od 25. 4. 2018. godine.

Tako je u Odluci br. 640 Mal 04673918 Spp Vrhovni sud FBiH odbio zahtjev Općinskog suda u Širokom Brijegu za rješavanje spornog pravnog pitanja te naveo: (...) da bi se ra- 
nije sporno, te da nije od značaja za odlučivanje u konkretnom predmetu postupka pred prvostupanjskim sudom, što dalje znači da nije od značaja za odlučivanje ni u većem broju predmeta, nisu ispunjeni formalni uvjeti zahtjeva propisani odredbom čl. 61. a. st. 1. ZPP-a FBiH, i u tom slučaju može sam, bez da upućuje zahtjev za rješavanje spornog pravnog pitanja Vrhovnom sudu $\mathrm{FBiH}$, rješenjem odbiti prijedlog stranke. Ovo rješenje ima značaj rješenja kojim se upravlja postupkom radi čega protiv njega nije dopuštena posebna žalba. ${ }^{58}$ Premda je sam zakonodavac propustio da normira način postupanja prvostupanjskog suda u toj situaciji, ovakav stav Vrhovni sud FBiH je prvi put zauzeo u Odluci br. 650 Ps 02186717 Spp 2, ${ }^{59}$ te ponovio u svojim kasnijim odlukama, ${ }^{60}$ čime je riješio dvojbu prvostupanjskih sudova kako postupiti u situaciji kada smatra da postavljeno pitanje ne predstavlja sporno pravno pitanje.

\subsubsection{Pitanje od značaja za odlučivanje u postupku pred prvostupanjskim sudom}

Sljedeći uvjet koji treba biti ispunjen za pokretanje postupka radi rješavanja spornog pravnog pitanja pred Vrhovnim sudom $\mathrm{FBiH}$ jeste da je pitanje, koje se pred prvostupanjskim sudovima pojavilo kao sporno, od značaja za odlučivanje $\mathrm{u}$ postupku pred prvostupanjskim sudom. Iako se ne radi o zakonskom rješenju prema kojemu bi sporno pitanje bilo od prejudicijalnog značaja ${ }^{61}$ za odlučivanje $u$ predmetu postupka, neki autori drže da bi ono moralo biti od prejudicijalnog značaja za odlučivanje u većem broju predmeta jer bi u protivnom traženje odgovora na bilo koje drugo sporno pravno pitanje dovelo do izigravanja ovog procesnog instituta. ${ }^{62}$ I Vrhovni sud $\mathrm{FBiH}$ je u svojim odlukama zauzeo ovakav stav, što znači da bi trebalo da se radi o pitanju koje uvjetuje donošenje odluke o tužbenom

dilo o spornom pravnom pitanju isto treba da bude sporno za sud, a ne za stranku i da postoji potreba da se zauzme stav o spornom pravnom pitanju. Iz navoda podnositelja zahtjeva proizlazi da to pitanje nije sporno za sud (dugogodišnja jedinstvena praksa, jedinstveno mišljenje svih sudaca tog suda i jedinstveni stavovi Županijskog suda u Širokom Brijegu), pa dakle nema potrebe da se zauzima stav o spornom pravnom pitanju jer takav stav već postoji. Vidi Odluku Vrhovnog suda FBiH br. 640 Mal 04673918 Spp od 11. 5. 2018. godine.

Vidi čl. 81. st. 3. ZPP FBiH. Istovjetne su odredbe čl. 81. st. 3. ZPP RS i čl. 205. st. 3. ZPP BD.

Vidi Odluku Vrhovnog suda FBiH br. 650 Ps 02186717 Spp 2 od 18. 10. 2017. godine.

Vidi Odluku Vrhovnog suda FBiH br. 320 Rs 31116317 Spp od 20. 12. 2017. godine, br. 230 V 03785718 Spp od 14. 1. 2019. godine i br. 230 I 02523118 Spp 2 od 20. 2. 2019. godine.

$61 \quad$ Kao što je bilo predviđeno odredbom čl. 176. st. 1. ZPP Srbije iz 2004.

Vidi Popović, o. c., str. 4. - 5. 
zahtjevu, ${ }^{63}$ a ne da takav prijedlog bude stavljen nakon što je okončan prvostupanjski postupak. ${ }^{64}$

\subsubsection{Pitanje od značaja za odlučivanje u većem broju predmeta}

Treći uvjet koji mora biti ispunjen da bi se prvostupanjski sud mogao obratiti zahtjevom za rješavanje spornog pravnog pitanja Vrhovnom sudu FBiH jeste da se sporno pravno pitanje pojavljuje u većem broju predmeta. Ovdje se radi o pravnom standardu. Međutim, prema prihvaćenoj praksi Vrhovnog suda $\mathrm{FBiH}$ to mogu biti i dva predmeta. ${ }^{65}$ Dužnost je prvostupanjskog suda da u zahtjevu navede da se pitanje kao sporno pojavilo u većem broju predmeta, kao i da navede koji su to predmeti. Ako u zahtjevu izostane ovaj podatak, Vrhovni sud $\mathrm{FBiH}$ odbacit će zahtjev kao nepotpun, jer prilikom zauzimanja stava o spornom pravnom pitanju Vrhovni sud FBiH ne rješava konkretan slučaj. ${ }^{66}$

63 Tako je u svojoj Odluci br. $681 \mathrm{Mal} 00676019$ Spp Vrhovni sud FBiH odbio zahtjev Općinskog suda u Livnu, Odjeljenje suda u Drvaru, za rješavanje spornog pravnog pitanja koje se ticalo urednosti prijedloga za ovrhu vezanu uz zahtjev za utvrđivanje ovršenikove imovine prema odredbi čl. 37. st. 1. Zakona o ovršnom postupku Federacije BiH. Navedena pitanja ovaj je sud postavio nakon što je već bio donio rješenje o ovrsi kojim je u cijelosti usvojio prijedlog za ovrhu (popisom, procjenom, pljenidbom i prodajom pokretnih stvari ovršenika na adresi ovršenika koje se nađu u njegovom vlasništvu), s tim da se u konkretnom slučaju nije radilo o situaciji iz st. 2. čl. 37. ZOP-a FBiH, odnosno o tome da je zahtjev za utvrđivanjem dužnikove imovine istaknut nakon donošenja rješenja o ovrsi jer ovrha na predloženom sredstvu nije uspjela. U svojoj odluci Vrhovni sud FBiH je pojasnio da pitanja o urednosti prijedloga za ovrhu vezana uz zahtjev za utvrđivanje ovršenikove imovine egzistiraju samo prije donošenja rješenja o ovrsi prema čl. 37. st. 1. ZOP-a FBiH, dok od trenutka donošenja rješenja o ovrsi sva pitanja, koja je definirao prvostupanjski sud, prestaju biti od značaja, radi čega je odlučio da zahtjev za rješavanje spornog pravnog pitanja ne ispunjava uvjete iz čl. 61a. st. 1. ZPP FBiH da bi se po istom moglo meritorno odlučivati odnosno da postavljeno pitanje u konkretnom slučaju nije od značaja za odlučivanje o predmetu postupka. Vidi Odluku Vrhovnog suda FBiH br. 681 Mal 00676019 Spp od 12. 11.2019. godine. Vidi Odluku Vrhovnog suda FBiH br. 650 P 72569619 Spp od 10. 7. 2019. godine. 
KEVO, M., BELOVIĆ, M., Postupak za rješavanje spornog pravnog pitanja s osvrtom na prethodni postupak pred... Zbornik radova Pravnog fakulteta Sveučilišta u Mostaru, br. XXIX., 2021., str. 42. - 67.

\section{SADRŽAJ ZAHTJEVA ZA RJEŠAVANJE SPORNOG PRAVNOG PITANJA}

Sadržaj zahtjeva kojim prvostupanjski sud pokreće postupak za rješavanje spornog pravnog pitanja određen je zakonom i sadrži kratak prikaz utvrđenog stanja stvari u konkretnoj pravnoj stvari, navode stranaka o spornom pravnom pitanju i razloge zbog kojih se sud obraća sa zahtjevom za rješavanje spornog pravnog pitanja. Sud će uz zahtjev priložiti i vlastito tumačenje spornog pravnog pitanja. ${ }^{67}$ Ako zahtjev ne sadrži sve prednje pobrojane elemente, Vrhovni sud FBiH odbacit će zahtjev kao nepotpun. ${ }^{68}$ Dužnost prvostupanjskog suda da uz zahtjev priloži sopstveno tumačenje, onemogućuje sud da ovaj postupak koristi da bi pribavio mišljenje od Vrhovnog suda o određenom pravnom pitanju iako za to ne postoje zakonom propisani uvjeti. ${ }^{69}$ Sud nije dužan svoj zahtjev za rješavanje spornog pravnog pitanja dostavljati strankama na izjašnjavanje budući da se radi o potrebi da najviši sud u državi zauzme pravni stav. ${ }^{70}$ Međutim, ako stranka predloži pokretanje postupka za rješavanje spornog pravnog pitanja, a protivna stranka nije bila u mogućnosti izjasniti se o prijedlogu, zakonodavac je propisao da će sud u tom slučaju dostaviti prijedlog drugoj stranci na izjašnjenje u roku osam dana od dana dostavljanja prijedloga, ${ }^{71}$ čime je udovoljeno načelu kontradiktornosti zajamčenim čl. 5. ZPP FBiH. ${ }^{72}$ Zakonom nije određen rok u kojem je protivna stranka dužna dostaviti svoj odgovor na prijedlog pa ovaj rok određuje prvostupanjski sud. Isto tako zakonom nisu propisane nikakve procesnopravne posljedice ako protivna stranka ne dostavi odgovor na prijedlog, što

67

Vidi čl. 61b. st. 1. ZPP FBiH: Istovjetne su odredbe čl. 61b. st. 1. ZPP RS i čl. 162 st. 1. ZPP BD.

Vidi čl. 61c. ZPP F BiH. Istovjetne su odredbe čl. 61v. ZPP RS i čl. 163. st. 1. ZPP BD.

Vidi Račić, R., Postupak za rješavanje spornog pravnog pitanja, Zbornik radova, XI savjetovanje iz oblasti građanskog prava, Aktualna pitanja iz oblasti građanskog prava u $\mathrm{BiH}$, teorija - praksa, Jahorina, 2016., str. 129.

Vidi Stanković, G., Zakon o parničnom postupku; prema stanju zakonodavstva od 31. maja 2014. godine/objašnjenja, tumačenje i stvarni registar, 11. izd., Beograd, Službeni glasnik, 2018., str. 76.

Vidi čl. 61b. st. 2. ZPP FBiH. Istovjetne su doredbe čl. 61b. st, 2. ZPP RS i čl. 162. st. 3. ZPP BD.

Čl. 5. ZPP RS i čl. 5. ZPP BD. Propisivanjem ove obveze osigurava se i ostvarenje prava na pravično suđenje zajamčeno članom 6. stavka 1. EKLJP jer je osigurana procesna ravnopravnost (equality of arms, „jednakost oružja”). Europski sud pod načelom pravičnosti suđenja podrazumijeva, pored ostalih jamstava iz člana 6., stav 1. EKLJP, i načelo jednakosti oružja (procesne ravnopravnosti). Ono je jedno od najvažnijih prešutnih načela, koje nužno obuhvaća razumnu mogućnost stranaka da u postupku brani svoja prava pod uvjetima koji ga ne stavljaju u bitno nepovoljniji položaj u odnosu na njezinog protivnika. 
upućuje na zaključak da dostava odgovora na prijedlog nije dužnost već predstavlja mogućnost/pravo odnosno ovlaštenje protivne stranke.

\section{POKRETANJE POSTUPKA ZA RJEŠAVANJE SPORNOG PRAVNOG PITANJA}

Postupak za rješavanje spornog pravnog pitanja inicira prvostupanjski sud zahtjevom po službenoj dužnosti ili na prijedlog stranke. ${ }^{73}$ Međutim, kad stranka podnese prijedlog, to je samo inicijativa prvostupanjskom sudu za njegovo pokretanje jer se zahtjevom za rješavanje spornog pravnog pitanja Vrhovnom sudu FBiH uvijek obraća prvostupanjski sud. Ako prijedlog podnesu stranka ili njezin punomoćnik izravno bez zahtjeva prvostupanjskog suda s elementima propisanim čl. 61b. st. 1. ZPP FBiH, Vrhovni sud FBiH će takav zahtjev odbaciti kao nedozvoljen. ${ }^{74,75}$ Prvostupanjski sud dužan je da, uz zahtjev za rješavanje spornog pravnog pitanja, dostavi predmet Vrhovnom sudu $\mathrm{FBiH} .{ }^{76}$

Postupak za rješavanje spornog pravnog pitanja odvija se u dvije faze. Jedna je ona koja se odvija pred prvostupanjskim sudom prilikom odluke o upućivanju zahtjeva za rješavanje spornog pravnog pitanja, a druga pred Vrhovnim sudom $\mathrm{FBiH}$ prilikom donošenja odluke o istom. Sud koji je pokrenuo postupak za rješavanje spornog pravnog pitanja dužan je zastati s postupkom dok se ne okonča postupak pred Vrhovnim sudom Federacije. ${ }^{77} \mathrm{U}$ ovom slučaju sud donosi rješe-

Vidi čl. 61 a. st. 1. ZPP FBiH. Istovjetne su odredbe čl. 61a st. 1. ZPP RS i čl. 161. ZPP BD. Vidi čl. 61c st. 1. ZPP FBiH. Istovjetne su odredbe čl. 61v. st. 1. ZPP RS i čl. 163. ZPP BD. Tako je u svojoj Odluci br. 700 P 00650918 Spp Vrhovni sud FBiH prijedlog ovršenika za rješavanje spornog pravnog pitanja odbacio kao nedozvoljen te naveo: (...) Kako je u konkretnom slučaju punomoćnik ovršenika dostavio prijedlog neposredno ovom sudu, bez zahtjeva suda koji sadrži ostale elemente propisane čl. 61. b. ZPP FBiH kao uvjeta za postupak rješavanja spornog pravnog pitanja pred ovim sudom, proizlazi da je prijedlog nedozvoljen za rješavanje u postupku spornog pravnog pitanja, jer nije podnesen od neovlaštene osobe. Vidi Odluku Vrhovnog suda FBiH br. 700 P 00650918 Spp od 12. 2. 2018. godine. Pogledaj i Odluke Vrhovnog suda FBiH br. 700 P 00654718 Spp od 20. 7. 2018. godine, br. 700000625317 Spp od 5. 7. 2017. godine, br. 700 Rs 00622817 Spp od 22.05.2017. godine, br. 700 Rs 00609417 Spp od 10.3. 2017. godine, br. 700 Rs 006207 17 Spp od 10. 3. 2017. godine, br. 700 P 00613717 Spp od 10. 3. 2017. godine, br. 320 Rs 26580816 Spp od 23. 9. 2016. godine, br. 410 P 05135516 Spp od 20. 4. 2016. godine, br. $510 \mathrm{Mal} 10541716 \mathrm{Spp}$ od 25. 5. 2016. godine, br. 180 P 02070416 Spp od 20. 4. 2016. godine, br. 510 Rs 10898116 Spp od 16.3.2016. godine.

Vidi čl. 61 b st. 3. ZPP FBiH. Istovjetne su odredbe čl. 61b st. 3. ZPP RS i čl. 161. ZPP BD. Vidi čl. 61a. st. 2. ZPP FBiH. Istovjetne su odredbe čl. 61a st. 2. ZPP RS i čl. 161. ZPP BD. 
nje o zastoju postupka u kome se rok zastoja određuje opisno odnosno navodi da će sud zastati s postupkom dok se ne okonča postupak pred Vrhovnim sudom FBiH. Zakonodavac nije propisao dužnost prvostupanjskog suda da obavijesti Vrhovni sud FBiH o postupovnim okolnostima koje bi dovodile do okončanja postupka (npr. o povlačenju tužbe, mirnom rješenju spora i sl.). Ali kako je odredbom čl. 61a st. 1. ZPP FBiH kao jedan od uvjeta za rješavanje spornog pravnog pitanja propisano da je ono od značaja za odlučivanje u postupku pred prvostupanjskim sudom, mišljenja smo da je dužnost prvostupanjstupanjskog suda da o svakoj takvoj okolnosti obavijesti Vrhovni sud FBiH jer se u slučaju njihovog nastupanja više ne bi radilo o spornom pravnom pitanju, odnosno ono prestaje biti od značaja za odlučivanje u konkretnom predmetu.

\section{ODLUKE VRHOVNOG SUDA O SPORNOM PRAVNOM PITANJU}

Ako je Vrhovni sud FBiH odlučio da rješava sporno pravno pitanje, odluku donosi po pravilima postupka za usvajanje pravnih stavova. ${ }^{78,}{ }^{79}$ Sam postupak rješavanja spornog pravnog pitanja pred Vrhovnim sudom $\mathrm{FBiH}$ propisan je odredbama čl. 13. - 17. Poslovnika o radu Građanskog odjeljenja Vrhovnog suda Federacije BiH. ${ }^{80}$ Prema odredbi čl. 13., prijedlog za rješavanje spornog pravnog pitanja izvjestitelj dostavlja predsjedniku odjeljenja i svim sucima. Prijedlog sadrži navode zahtjeva za rješavanje spornog pravnog pitanja, procesne pretpostavke, pravne norme koje se odnose na slučaj, pravnu analizu i prijedlog odluke. Po prijemu prijedloga, predsjednik odjeljenja dužan je elektronskim putem zakazati sjednicu odjeljenja, ${ }^{81}$ ali ne u roku kraćem od 5 dana. ${ }^{82}$ Građansko odjeljenje raspravlja o prijedlogu tako što sudac izvjestitelj izlaže svoj prijedlog, a zatim predsjedavajući otvara raspravu o prijedlogu odluke o zahtjevu. Ono što je bitno za donošenje odluke o zahtjevu jeste da se donosi većinom glasova svih sudaca

78 Vidi čl. 61d. st. 1. ZPP FBiH, odnosno čl. 61 g. ZPP RS i čl. 164. st.1. ZPP BD.

79 Mogućnost zauzimanja pravnih shvaćanja sudskih odjeljenja Vrhovnog suda FBiH i Apelacionog suda Brčko distrikta $\mathrm{BiH}$, koja se dostavljaju nižim sudovima i za koje su upućujućeg karaktera predviđena je čl. 19. Pravilnika o unutrašnjem sudskom poslovanju BiH, “Službeni glasnik BiH”, br. 66/2012, 40/2014, 54/2017, 60/2017 - ispravka i 30/2018.

Poslovnik o radu Građanskog odjeljenja Vrhovnog suda Federacije BiH - dalje - Poslovnik, dostupno na: vsud-fbih.pravosudje.ba

Čl. 5. st. 4. Poslovnika propisano je da će sjednica Građanskog odjeljenja biti obavezno sazvana kada se zahtjevom pokrene postupak za rješavanje spornog pravnog pitanja pred Vrhovnim sudom Federacije BiH u skladu s članom 61.a) ZPP FBiH.

Vidi čl. 13. Poslovnika. 
odjeljenja. ${ }^{83}$ Prilikom glasanja sudac ne može biti suzdržan. ${ }^{84} \mathrm{O}$ radu sjednice odjeljenja vodi se zapisnik u koji se unose rezultati glasanja povodom pojedinačnih pitanja ${ }^{85}$ Odluku o spornom pravnom pitanju izrađuje sudac izvjestitelj. Izreka odluke mora sadržavati jasno definirano pravno shvaćanje, dok obrazloženje čini sadržaj zahtjeva za rješavanje spornog pravnog pitanja, razloge dopuštenosti, propise na koji se odnose i pravnu analizu u skladu s pravnim shvaćanjem. Potpisanu odluku izvjestitelj dostavlja svim sucima, predsjedniku odjeljenja i službeniku zaduženom za održavanje web-stranice suda. ${ }^{86}$

Ako nisu ispunjeni uvjeti za donošenje meritorne odluke o spornom pravnom pitanju, Vrhovni sud FBiH odbacit će zahtjev kao nepotpun ili nedozvoljen.

Zahtjev je nepotpun ako ne sadrži sve elemente propisane odredbom čl. 61b. st. 1. ZPP FBiH, a nedozvoljen ako je Vrhovni sud $\mathrm{FBiH}$ o tome zahtjevu već donio odluku. ${ }^{87}$ Vrhovni sud $\mathrm{FBiH}$ odbacit će zahtjev kao nedozvoljen i kada o spornom pravnom pitanju postoji ustaljena sudska praksa, odnosno stavovi Vrhovnog suda izraženi u odlukama po reviziji kao vanrednom pravnom lijeku ${ }^{88}$ ili u odlukama Ustavnog suda $\mathrm{BiH} .{ }^{89}$

Vrhovni sud FBiH odbit će riješiti sporno pravno pitanje ako ono nije od značaja za odlučivanje u većem broju predmeta u postupku pred prvostupanjskim sudom. Vrhovni sud $\mathrm{FBiH}$ dužan je riješiti sporno pravno pitanje u roku 60 dana od

$83 \quad$ Vidi čl. 14. Poslovnika.

${ }_{84} \quad$ Vidi čl. 12. st. 2. Poslovnika.

85 Vidi čl. 17. Poslovnika.

Vidi čl. 15. Poslovnika.

Vidi čl. 61. c ZPP FBiH, odnosno čl. 61. v. ZPP RS, te čl. 163. ZPP BD.

Ovakav stav Vrhovni sud FBiH je izrazio u Odluci br. 320 Ps 26867818 Spp i pojasnio: (...) Odredbom čl. 61 c. st. 1. ZPP FBiH propisano je da će Vrhovni sud FBiH odbaciti kao nepotpun ili nedozvoljen zahtjev za rješavanje spornog pravnog pitanja, između ostalih, i u slučaju predviđenom u st. 2. iste odredbe, kojom je propisano da je "zahtjev iz st. 1. ovog člana nedozvoljen ako je o takvom zahtjevu Vrhovni sud FBiH već donio odluku". S tim u vezi, a u skladu s naprijed citiranom zakonskom odredbom, ovaj sud je na sjednici Građanskog odjeljenja od 31. 5. 2018. godine zauzeo i pravni stav da "ako je Vrhovni sud F BiH u nekoj svojoj odluci ili na sjednici odjeljenja već odlučio o takvom pitanju, takav zahtjev treba odbaciti temeljem odredbi čl. 61. c st. 2. ili 61 f. ZPP F BiH." Vidi Odluku Vrhovnog suda FBiH br. 320 Ps 26867818 Spp od 19. 10. 2018. godine. Pogledaj i Odluke Vrhovnog suda FBiH br. 650 P 46204516 Spp od 9. 6. 2016. godine i br. 320 Ps 19054916 Spp od 23. 9. 2016. godine.

Vidi Odluke Vrhovnog suda FBiH br. 530 Rs 06218516 Spp od 23. 9. 2016. godine, br. 65 0 V 63802817 Spp od 22. 5. 2017. godine. 
dana prijema zahtjeva. ${ }^{90} \mathrm{U}$ odluci kojom odlučuje o spornom pravnom pitanju Vrhovni sud $\mathrm{FBiH}$ iznosi razloge kojima obrazlaže zauzeto pravno shvaćanje. ${ }^{91}$ Odluka o spornom pravnom pitanju dostavlja se sudu koji je pokrenuo postupak i objavljuje na internetskoj stranici Vrhovnog suda Federacije ili na drugi pogodan način. ${ }^{92}$

Ako je Vrhovni sud FBiH riješio sporno pravno pitanje, stranke u postupku u kome se postavlja isto sporno pravno pitanje nemaju pravo tražiti njegovo rješavanje u parnici koja je u tijeku..$^{93}$ Ako se prvostupanjski sud ipak obrati zahtjevom Vrhovnom sudu FBiH da se ponovno izjasni o zahtjevu o kome je već donio odluku, takav zahtjev bit će odbačen kao nedozvoljen.

Ova odredba upućuje na zaključak da je sud pred kojim se pojavilo sporno pravno pitanje vezan pravnim shvaćanjem Vrhovnog suda $\mathrm{FBiH}$ i da stranke nisu ovlaštene tražiti rješenje pravnog pitanja na drugačiji način, i to ne samo u parnicama koje su u tijeku, već i u naknadno pokrenutim parnicama. ${ }^{94} \mathrm{Da}$ su nižestupanjski sudovi vezani odlukom koju donosi Vrhovni sud $\mathrm{FBiH}$, proizlazi posredno i iz odredbe čl. 61c st. 2. ZPP FBiH. Međutim, zakonodavac je propustio normirati da ova odluka ima obvezujuću snagu za nižestupanjske sudove, jer bi, kako to navode pojedini autori, na taj način ustanovio novi izvor prava odnosno u parničnoj proceduri uspostavio precedent.${ }^{95}$ Mišljenja smo da odluke Vrhovnog suda FBiH o spornom pravnom pitanju ne predstavljaju izvor prava. Njegove odluke imaju isti značaj kao preliminarne (interpretativne) odluke Suda EU i sačinjene su po uzoru na odredbe o ovim odlukama. Poenta je u tome da su nižestupanjski sudovi vezani jednom riješenim spornim pitanjem (iako to nije izričito rečeno). Ta vezanost proistječe iz uloge najvišeg suda u državi - da se

Vidi čl. 61d st. 1. i 2. ZPP FBiH. Istovjetne su odredbe čl. 61g st. 2. i 3. ZPP RS i čl. 164. st. 2. i 3. ZPP BD.

Vidi čl. 61e st. 1. ZPP FBiH. Istovjetne su odredbe čl. 61d st. 1. ZPP RS, te čl. 165. st. 1. ZPP BD.

Vidi čl. 61e st. 2. ZPP FBiH. Istovjetne su odredbe čl. 61d st. 2. ZPP RS i čl. 165. st. 2. ZPP BD.

Vidi čl. 61f. ZPP FBiH, odnosno čl. 61đ ZPP RS, te čl. 166. ZPP BD.

Tako je u Odluci br. 510 Rs 11202516 Spp Vrhovni sud FBiH odbacio zahtjev općinskog suda za rješavanje spornog pravnog pitanja te naveo: „(...) kako se podnesenim zahtjevom traži razrješenje istog spornog pravnog pitanja, koje je već ranije postavljeno od strane prvostupanjskog suda i koje je Vrhovni sud riješio, to je isti nedozvoljen, jer se u postupku u kome se postavlja isto sporno pravno pitanje, nema pravo tražiti njegovo rješavanje u parnici koja je u tijeku. "Vidi Odluku Vrhovnog suda FBiH br. 510 Rs 112025 16 Spp od 17. 3. 2017. godine.

Tako i Račić, Postupak..., cit u bilj. 67., str. 131. 
brine o jedinstvenoj primjeni i tumačenju prava, da bi se postigla ravnopravnost stranaka u postupku pred sudom i pravna sigurnost (izvjesnost) da će ista prejudicijalna pitanja biti rješavana na isti način. ${ }^{96}$

\section{ZAKLJUČAK}

Postupak za rješavanje spornog pravnog pitanja uveden je u naš procesni sustav po uzoru na postupak prethodnog odlučivanja pred Europskim sudom. Usporedbom postupka za rješavanje spornog pravnog pitanja u našem pravu s postupkom za rješavanje spornog pravnog pitanja u Republici Srbiji uočava se da su ova dva postupka uređena na gotovo identičan način. Jedina razlika ogleda se u tome što po ZPP Srbije kad stranka predloži pokretanje postupka za rješavanje spornog pravnog pitanja prvostupanjski sud može (ne mora) dostaviti prijedlog suprotnoj stranci na izjašnjavanje, ako nije bila u mogućnosti da se izjasni o prijedlogu, dok je po našim procesnim zakonima to dužnost suda, što je bolje rješenje jer se na ovaj način udovoljava načelu kontradiktornosti u ovom postupku. Uz to rok za izjašnjenje protivne strane o prijedlogu u ZPP Srbije iznosi 15 dana (čl. 181. st. 2. ZPP Srbije), a u našim procesnim zakonima 8 dana (čl. $61 \mathrm{~b}$ st. 2. ZPP FBiH). Njegovom usporedbom s postupkom prethodnog odlučivanja pred Europskim sudom i oglednim postupkom u RH uočavaju se određene sličnosti i razlike. Sličnosti ovih procesnopravnih instituta ogledaju se u ciljevima koji se njima žele ostvariti - povećanje doprinosa pravnoj sigurnosti i osiguranje jedinstvene primjene prava.

Razlike između postupka za rješavanje spornog pravnog pitanja u $\mathrm{FBiH}$, te postupka prethodnog odlučivanja pred Sudom EU i oglednog postupka u Hrvatskoj postoje u odnosu na njihovo pokretanje. Postupak za rješavanje spornog pravnog pitanja prema ZPP FBiH prvostupanjski sud može pokrenuti po službenoj dužnosti (ex officio) ili na prijedloga stranke (čl. 61b ZPP FBiH), a postupak prethodnog odlučivanja pred Sudom EU samo nacionalni sud, odnosno ogledni postupak može pokrenuti samo prvostupanjski sud pred kojim se pojavilo sporno pravno pitanje (čl. 502.k, st. 1. ZPP RH). Međutim, neovisno o tome što se u $\mathrm{FBiH}$ postupak može pokrenuti i po prijedlogu stranke, jedino aktivno legitimirano tijelo za pokretanje postupka u svim ovim postupcima je sud. Sud koji je pokrenuo postupak dužan je zastati s postupkom dok se ne okonča postupak pred Vrhovnim sudom FBiH (čl. 61a st. 2. ZPP FBiH), a nacionalni sud države članice no i dopunjeno izdanje, Pravni fakultet Univerziteta Union, Beograd, 2015., str. 346. 
i sud u oglednom postupku RH može odrediti prekid postupka (čl. 213, st. 2., t. 3 ZPP RH). Vrijeme potrebno za donošenje odluke puno je kraće u u postupku za rješavanje spornog pravnog pitanja - 60 dana (čl. 61d st. 3. ZPP FBiH), dok je znatno dulje u oglednom postupku - najmanje 135 dana jer se odvija u nekoliko stadija (15, 30 i 90 dana). Sljedeća razlika ogleda se u učincima odluka koje donose ovi sudovi. Tako u državama članicama odluke Suda EU imaju izravan učinak i djeluju erga omnes. Sud EU je kroz svoju praksu zauzeo stav da one stupaju na snagu od dana kada je tumačeno pravilo stupilo na snagu, da su takve odluke deklaratorne i djeluju ex tunc (retroaktivno). Isto tako u ZPP RH zakonadavac je izričito propisao da je nakon donošenja pravnog shvaćanja Vrhovnog suda Republike Hrvatske sud u nastavljenim postupcima vezan tim pravnim shvaćanjem (čl. 502. n ZPP RH).

U bosanskohercegovačkim procesnim zakonima zakonodavac je propustio da zauzme stav o tome kakav učinak imaju pravna shvaćanja izražena u odlukama Vrhovnog suda o spornim pravnim pitanjima, što može narušiti svrhu ovog postupka. Ovo iz razloga što još uvijek jedan određeni dio pravne zajednice smatra da odluke Vrhovnog suda o spornom pravnom pitanju ne vežu prvostupanjske sudove, jer u našim procesnim zakonima sudske odluke ne predstavljaju izvor prava, što dalje opet dovodi do različitog postupanja čak i nakon zauzetog stava o spornom pitanju. U Zakonu o parničnom postupku $\mathrm{FBiH}$ de lege ferenda trebalo bi unijeti izmjene da se po uzoru na ZPP RH propiše da je nakon donošenja pravnog shvaćanja Vrhovnog suda $\mathrm{FBiH}$ sud u nastavljenim postupcima vezan tim pravnim shvaćanjem. Ovakve izmjene, gdje bi odluke Vrhovnog suda FBiH o spornom pravnom pitanju izričito (ne posredno) vezale nižestupanjske sudove, ispunile bi u cijelosti smisao uvođenja ovog procesnopravnog instituta u naš pravni sustav.

$\mathrm{Na}$ kraju, BiH je potpisnica Sporazuma o stabilizaciji i pridruživanju čime se obvezala svoje zakonodavstvo uskladiti s pravnom stečevinom Europske unije. Bosna i Hercegovina je 15. veljače 2016. godine podnijela zahtjev za članstvo u Europskoj uniji, koji za državu članicu, koja pristupa Uniji, podrazumijeva pristup pravnoj stečevini (acquis communautaire) Europske unije. Svaka država koja želi pristupiti u članstvo Europskoj uniji mora prihvatiti osnivačke ugovore i uskladiti svoje zakonodavstvo s pravnom stečevinom Europske unije. Gledajući s optimizmom da će Bosna i Hercegovina uskoro ući u članstvo Europske unije, bosanskohercegovački sudovi će postati dio europskog sudskog sustava, a bosanskohercegovački suci europski suci koji će biti u obvezi poznavati i izravno primjenjivati tumačenja norme prava EU-a koja je u svojim odlukama dao Sud EU. U tom smislu je, već sada, nužna edukacija sudaca kako bi se što bolje upoznali s postupkom prethodnog odlučivanja. 


\title{
PROCEDURE FOR RESOLVING A DISPUTED LEGAL ISSUE WITH REFERENCE TO THE PREVIOUS PROCEDURE BEFORE THE EUROPEAN COURT OF JUSTICE
}

\begin{abstract}
Summary: The Law on Amendments to the Civil Procedure Code of the Federation of Bosnia and Herzegovina from 2015 brought numerous novelties in civil procedure. One of them is the introduction of the institute of resolving a disputed legal issue. After article 61, article 14 of the Law on Amendments to the Law on Civil Procedure Code of the Federation of Bosnia and Herzegovina from 2015 added a new chapter III $a$, and Art. 61a to 61 f under the title-Procedure for resolving a disputed legal issue. The reasons for introducing this legal institute into our legal system are reflected in the contribution to legal security and equality before the courts of first instance, and in increasing the efficiency and economy of the procedure. This institute is compared to the preliminary ruling procedure before the European Court of Justice.

The paper will analyse the provisions of the Procedure for resolving the disputed legal issue, and special attention will be given to the analysis of the practice of the Supreme Court of the Federation of Bosnia and Herzegovina related to this institute. Generally the legal nature of the procedure for resolving a disputed legal issue is examined, the conditions and persons authorized to initiate it are considered, as well as the decisions of the Supreme Court of the Federation of Bosnia and Herzegovina on the disputed legal issue. The preliminary ruling procedure before the European Court of Justice will be considered in advance. Solutions in comparative law will also be pointed out.
\end{abstract}

Keywords: European Court, national courts, Supreme Court of the Federation of Bosnia and Herzegovina, procedure for resolving a disputed legal issue, disputed legal issue. 